\title{
European youth work policy and young people's experience of open access youth work ${ }^{i}$
}

By Jon Ord, Marc Carletti, Daniele Morciano, Lasse Siurala, Christophe Dansac, Sue Cooper, Ian Fyfe, Kaur Kösti, Eeva Sinisalo-Juha, , Marti Taru \& Manfred Zentner

\section{Word count 8,079}

Key words: Youth Work, European Youth Work Policy, Impact of Youth Work, Experience of Young People, Friendship \& Sociability,

\begin{abstract}
This article examines young people's experiences of open access youth work in settings in the UK, Finland, Estonia, Italy and France. It analyses 844 individual narratives from young people which communicate the impact of youthwork on their lives. These accounts are then analysed in the light of the European youth work policy goals. It concludes that it is encouraging that what young people identify as the positive impact of youth work are broadly consistent with many of these goals. There are however some disparities which require attention. These include the importance young people place on the social context of youth work, such as friendship, which is largely absent in EU youth work policy; as well as the importance placed on experiential learning. The paper also highlights a tension between 'top down' policy formulation and the 'youth centric' practices of youth work. It concludes with a reminder to policy makers that for youth work to remain successful the spaces and places for young people must remain meaningful to them 'on their terms'.
\end{abstract}

Corresponding author: Jon Ord, University of St Mark \& St John, Plymouth, UK jord@marjon.ac.uk

Marc Carletti, IUT Figeac, Toulouse Jean-Jaurès Université, France

Daniele Morciano, University of Bari, Italy

Susan Cooper, University of St Mark \& St John, Plymouth, UK

Christophe Dansac, IUT Figeac, Toulouse Jean-Jaurès Université, France

Ian Fyfe, University of Edinburgh, Scotland, UK

Kaur Kötsi, University of Tartu Narva College, Estonia

Eeva Sinisalo-Juha, HUMAK (University of Applied Sciences), Finland

Lasse Siurala Tallinn University, Estonia

Marti Taru, Tallinn University, Estonia

Manfred Zentner, Danube University, Krems, Austria 


\section{Introduction}

The participation of young people in the design, construction and delivery of youth work is widely accepted (Fitzsimons, et al, 2011; NYA, 2018; Ord, 2016). This process is exemplified by the expression 'doing things with as opposed to doing things for' (Ord 2016: 67) or by the phrase popularised during the response to the AIDS crisis in the 1980's: 'Nothing for us, without us' (UNAIDS, 2020). Youth work embraces the idea that young people should be co-creators. As a result, the appreciation of, and the appropriate responses to, young people's experiences of youth work are essential to successful practice.

The participation of service users in other sectors may be less widely established but there is an increasing recognition of the importance of young people's experience as a key factor in both establishing and maintaining successful provision. These range from education, training and employment (Unwin \& Wellington, 2001); housing (Visser 2020); criminal justice (Larkins \& Wainwright, 2020); and health (Ambresin et al, 2013). The importance of young people's experience is also being increasingly merited in establishing the effects of digital media interventions such as web- based sexual health provision (Davis et al, 2012) and cyberbullying (Denney, 2020). Such commitments to participation place particular importance on the lived experience of young people.

Within this context, this paper analyses 844 stories from young people which communicate their experiences of the impact of youth work. It begins with a review of the main policy priorities of youth work, set out within the institutions of the European Commission (EC) and the Council of Europe $(\mathrm{CoE})$. The stories are then analysed in the context of the role youth work is deemed to play in fulfilling the policy goals of the European institutions.

\section{European youth work policy}

\section{Origins}

In recent years, the EU, the $\mathrm{EC}$ and the $\mathrm{CoE}$ have placed increasing priority on youth work, publishing a range of policy documents which locate youth work centrally in the fulfilment of a number of its policy goals. The origins of these initiatives are somewhat contentious. For example, in a recent joint publication by the EU and the CoE, Gavrielides (2017: 213) argues that the history of youth policy in Europe started with the 'White Paper on Youth' (EC, 
2001), however developments clearly predate this. One of the problems in specifying the exact timeline is the conflation of youth policy and youth work policy. A key marker however is perhaps the establishment of the European Youth Centre in Strasbourg in 1972, the aims of which include: 'the training of youth leaders in a European context' $(\mathrm{CoE}$, 2020a). However, the associated youth mission and mandate has little mention of youth work. Another key marker was the first 'European Conference of Ministers Responsible for Youth' which took place in Strasbourg in 1985, this included promotion of the European Youth Week (CoE, 2020b). The CoE also initiated the review of member state's youth policies, the first of which took place in Finland in 1999 which included an assessment of its youth work provision. In the early 1980's the European Parliament also promoted youth activities and volunteering, and later youth exchanges (European Parliament, 1983). The latter contained an early explicit reference to 'youth workers', who were deemed to play a key role in the youth exchange programme (Commission of the European Communities (CoEC), 1990).

The milestone in the European institutions' commitments to the development of youth work across Europe came in the early 1990s when the 'field of youth work' was established in the European funding streams, the precursors of what is now known as Erasmus+ (CoEC, 1993a; 1993b). ${ }^{\text {ii }}$ Erasmus+ is a major funding stream within the EU, a significant element of which supports and develops youth work. Its total allocation between 2014 and 2020 was $€ 14.8$ billion (Deloitte, 2014, p. 23), of which around $€ 134,000,000$ was allocated to Key

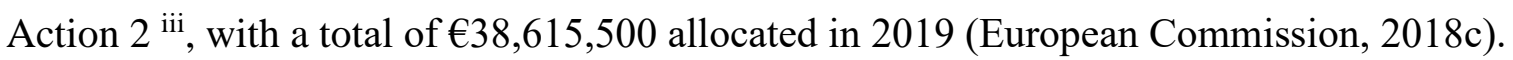

Youth work has now become an important vehicle through which the policy priorities of European institutions are being advanced. Examples of this included the CoE's 'All Different - All Equal' campaign (CoE, 1995), and its sister campaign against racism ten years later. Equally important was the publication of the 'European White Paper on Youth' (EC, 2001) which acknowledged the increasing exclusion of young people from public spheres and proposed 'new ways of enabling young people to participate in public life' (EC, 2001).

A seminal moment in European youth work policy formation came in 2010 when a council resolution on youth work was accepted, enacting a formal commitment to establish and promote the role of youth work across Europe:

The Treaty provides that EU action is to be aimed at encouraging the development of ... socio educational instructors (hereafter called 'youth workers and youth leaders'). 
The latest resolution reaffirms that youth work 'is a broad term covering a large scope of activities of a social, cultural, educational or political nature both by, with and for young people' (CofE 2020c). It has been acknowledged that this diversity across European contexts can create problems in understanding and defining youth work practice ((Bohn, 2008: 21, Williamson and Coussée, 2019). However, it recognised that youth work has fundamental guiding principles including an appreciation of, and concern for, 'the needs, aspirations, interests and attitudes of young people' (CoE, 2010: 2). The role and purpose of youth work has also been defined as a 'voluntary, youth centric, self-reflective and critical, value-driven and relational practice' (CoE, 2018b). The resolution has given youth work greater importance and placed it firmly within a range of European policy priorities.

\section{European youth work policy priorities}

The European policy goals for youth work were initially set in the context of the 'eight fields of action'. These were reemphasised in the 2010 Resolution. They are:

- Education and training

- Employment and entrepreneurship

- Health and well-being

- Participation

- Volunteering

- Social inclusion

- Youth and the world

- Culture

(CoE, 2010: 1)

For the purposes of youth work however, these eight fields were refined to two broad policy priorities outlined within the 2010 'Resolution on Youth Work'. They are to:

- create more and equal opportunities in education and in the labour market,

- promote the active citizenship, social inclusion and solidarity of all young people 
(CofE, 2010: 1)

Youth unemployment has been a key priority for the European Union, especially since the financial crisis of 2008, after which numerous youth specific policy initiatives were launched (Lahusan et al, 2013). A notable example is the 'Youth Guarantee' which has recently been reinforced (EC, 2020) with a pledge of $€ 22$ billion. The youth Guarantee is an attempt to improve the school-to-work transitions and a specific intervention to support and create jobs for young people. The importance of youth work within the EU's employability strategy is evident, identifying 'youth work as a resource to support youth employability' (CoEC, 2009: 6). Acknowledging the 'contribution of youth work to the creativity and entrepreneurship of young people' (CoEC, 2009: 7). However, the role of youth work is not limited to the economic sphere. Youth work is also tasked with addressing a range of social concerns, from tackling school failure and wider issues of social exclusion to providing greater leisure time opportunities for young people. Youth work is increasingly seen as playing a key role in: 'equipping young people with 'key competencies' and enabling a successful 'transition to adulthood' (EC, 2018a). European policy also envisages a fundamental role for youth work in enabling the participation of young people in civil society as identified by the Council of Europe:

Youth work makes an important contribution to active citizenship by providing opportunities to acquire the knowledge, skills and attitudes for civic engagement and social action.

(CoE, 2017: 2)

This contribution is identified in the realm of both human capital, developing specific skills and competences, as well as social capital, strengthening networks and relationships (EC, 2014: 7). Youth work's contribution is not restricted to the individual level, and it is acknowledged as an: 'an important component of our social fabric offering a space for contact, exchange and engagement among youth but also between generations' (EC, 2014: 8). Youth work is increasingly identified as playing a key role in EU policy priorities. The latest example of which is the publication of 'The Contribution of Youth Work to Preventing Marginalisation and Violent Radicalisation' (EC, 2017). 


\section{Introduction to the study and methodology ${ }^{\mathrm{iv}}$}

This article is based on a two-and-a-half-year study across six countries - two in the UK (England and Scotland ${ }^{\mathrm{v}}$ ), Finland, Estonia, Italy and France - with the aim of identifying the impact of youth work from young people's perspectives. The research was coordinated by the authors in their respective countries, and three youth work organisations were recruited by each coordinator via purposive sampling. Consistent criteria underpinning the selection of all 18 youth work organisations, was that they operated through voluntary participation. Most of the organisations were standard open access youth clubs, but one Finnish project was an online youth club, and one French organisation delivered detached youth work.

Young people were recruited 'purposively' - that is, they were identified by the youth worker as having a potentially interesting story to tell, based on their prior knowledge of the young people in the organisation. The age range of the young people covered the full range of both national and European youth work policy; for example, Estonian youth is defined as young people aged between 7 and 26 (Estonia, 2018). ${ }^{\text {vi }}$ The gender mix of the data was evenly distributed with 404 female stories and 422 male stories (18 were not identified by gender). The gender mix was also relatively even within countries, with the largest differences being within Italy, which had 83 males and 51 females, and England, which had 81 females and 62 males. No ethnicity data was collected as this was not culturally permissible in France.

The study produced six separate data sets. ${ }^{\text {vi }}$ Data was collected by youth workers, who were trained as researchers by the national coordinators. The data collection was congruent with youth work practice and involved an informal conversation between a young person and one of their youth workers. The resulting data comprised of co-constructed stories from the young people who identified the positive impact of youth work on their lives. This story generation utilised a participative evaluation method, entitled 'Transformative Evaluation', developed by Cooper (2018), an adaptation of the 'Most Significant Change' methodology originally developed by Davies (1996; see also Davies \& Dart, 2005). Young people consented to their involvement and youth workers faciliated the story collection, beginning the conversation with the question:

Looking back, what do you think has been the most significant change that occurred for you as a result of coming here? 
The data collection took place over one year, in three distinct cycles. Each of the stories was collected from a different young person, and no follow-up stories were obtained.

It should be noted that this study was constructed within a framework of 'appreciative enquiry' (Zandee \& Cooperrider, 2008), which is a strength-based form of analysis. That is, it is concerned with what we can learn from 'what works'. It should be noted that use of this method does not imply a belief that all youth work has positive effects; rather, this study was concerned with identifying the positive impact of youth work, hence its grounding in appreciative enquiry. The study assesses what the experiences of young people can tell us about the impact of youth work in six different European contexts and assesses the extent to which this impact is consistent with EU youth work policy priorities.

\section{Limitations}

Although extensive, drawing from over eight hundred accounts from young people related to the impact of youth work, this research is of course partial. Eight hundred voices is a lot in one sense, but in a continent of five hundred million people it is still a very small proportion of the whole. The data is also partial in that it is a 'best case scenario', because - given its basis in appreciative enquiry - by definition it only seeks positive stories of impact. The study does not take account of potentially limited or negative impacts of youth work, and neither does it account for the voices of those who do not access youth work or who are marginalised. More research needs to be done through a more critical lens, interrogating the processes and outcomes of youth work more broadly. This study identifies the positive potential of youth work when it is working well, but it cannot be inferred from our positive and specific examples of how well youth work is functioning that youth work is working well across the board.

\section{Findings}

As shown in Table 1 below, 844 stories were collected from young people, with an average of 141 stories per country. This ranges from 123 stories in Finland to 164 stories from Estonia.

Table 1. Total number of stories collected, by country and by cycle. 


\section{Introduction to analysis}

The stories were coded separately within the six country groups. It is acknowledged that coding is an 'interpretive act' and a 'heuristic' process (Saldana, 2016: 5), and that the coding process may have led to some differences in interpretation across national contexts. To mitigate against this, broad agreements and principles were established prior to the coding process. Nevertheless, it was important that each of the stories was analysed within its national context, free from the influences of either the principal investigator or coordinators from other countries.

The agreed process of coding collated a set of initial codes, these were subsequently reduced to a list of six to eight final codes (England, Finland and Italy had six final codes, Scotland had seven, Estonia and France had eight final codes). The final stage of analysis involved a detailed examination of all the final codes - independent of their country of origin - to identify any similarities among the final codes. This process was carried out as a collective group of researchers with no preconditions, and it produced a list of five overarching themes, each of which contained between five and nine final codes (see Table 2 below). Importantly the coding process was done without specific reference to, or indeed in several cases particularly detailed knowledge of, European youth work policy. Table 2 below presents the overarching themes with their associated final codes (and the country of origin).

Table 2. Five overarching themes and the associated final codes with the country of origin

\section{Findings: Young people's experience of youth work}

\section{Sense of self}

This theme was dominated by references to developing confidence. Four of the six data sets (Scotland, England, Estonia and France) identified 'confidence' as a final code. Of those that did not, Italy had an initial code of 'self-esteem', and Finland had initial codes of 'agency' and 'finding one's identity and personality'. For example:

I'm more self-confident. It has had a positive impact on my social life. 
Other final codes within this overarching theme included 'well-being', 'resilience', 'positive emotions' and 'self-determination'. They illustrate how young people feel more positively about themselves, their lives and their surroundings as a result of their experiences of youth work, for example:

I have become more social... I have met more people around my area and been more active.

(Female, aged 14, England)

\section{Creating places and spaces for young people}

This overarching theme is nuanced. It refers to how young people feel about the youth work settings - its atmosphere - which is an important aspect of youth work, for example the:

Relaxed and positive hustle, everybody was encouraging and happy

(Male, aged 18, Finland)

The code also refers to the relationships that youth workers build with young people, the sense of mutuality and the acceptance that young people feel:

Ifeel accepted here, not out in public or in the school. (Male, aged 15, Scotland)

The 'bottom line' for this theme is that youth work is 'fun', as expressed by one young person in the study:

I come here to have fun and enjoy myself.

(Male aged 11, France)

\section{Relating to others}

Over half of the final codes in the theme 'relating to others' relate to friendship. Either enhancing or making friends was one of the most consistent outcomes that young people identified throughout the stories. Four of the six countries identified 'friends' as a final code (Finland, England, Estonia and Scotland). Among the other two, France had an initial code of 'making friends' which helped form the final code 'creating bonds'. Italy had an initial code 
of 'new emotional bond (friend, love etc.)' which became part of the final code 'relating with others and valuing diversity':

MJC viii allowed me meet other people. Some of them were only holiday or afterschool friends (girls and boys)... Others became true friends. I met my two best friends at MJC.

(Female, aged 14, France)

I have made a lot of new friends and acquaintances.

(Male, aged 17, Estonia)

\section{Experiential learning}

This theme is diverse and wide-ranging. It covers outcomes of youth work such as the acquiring of new skills and abilities and the discovery of new activities, as well as increased opportunities. It also highlights the variety of settings that youth work takes place in. A core aspect of this theme also relates to learning and the provision of new or novel experiences outside formal settings. Examples include:

I have learned cooking, I have learned to organise events

(Female, aged 16, Finland)

We learn about autonomy and getting a better sense of organisation: preparing our own picnic, sorting things out with parents.

(Female, aged 17, France)

\section{Social inclusion}

This theme relates to young people's relationship to the social demands and expectations placed upon them. This includes accessing employment opportunities, re-engaging with school, stopping smoking or addressing alcohol issues. The stories relay important messages about how youth work 'fills the gaps', to re-connect young people who have been marginalized in some capacity and therefore addresses key aspects of social exclusion. Some examples relate to specific outcomes: 
The centre gave me the chance to discover a new world and a possible career

(Male, aged 18, Italy)

Other stories relate to changes in attitudes:

I would be, like, doing drugs and drinking, being a right good toe rag. But I started volunteering and I had to show the wee ones how to be a good role model.

(Female, aged 16, Scotland)

\section{Analysis of findings:}

\section{Young people's experiences of youth work \& European policy priorities}

'Sense of self' coheres well with European youth work policy discourse, which emphasises self-awareness, development and motivation (EC, 2014, 2015). 'Increasing confidence' is also widely recognised, as is self-esteem. For example, the EU Strategy acknowledges that: 'Youth work brings unique benefits to young people ... providing a safe environment for them to gain self-confidence' (EC, 2018a: 6). The well-being (and the health) of young people more generally is widely acknowledged with European youth work policy. It is one of the eight fields of action, as well as a focus of the Council of Europe Recommendation (CofE, 2010) and it is highlighted within other key European policy documents (EC, 2014). Other aspects of self are also specifically identified as desirable outcomes of youth work, such as resilience (EC, 2015: 84) self-determination (EC, 2015) and self-efficacy (CofE, 2020c). There are however fewer explicit references to emotions and feelings within EU youth work policy. There is one reference confirming that that young people 'are feeling more secure in life' (EC, 2014: 90) but explicit references to the emotional life of young people are infrequent. Given that young people's experience of youth work emphasises the importance of feelings and emotions this should be acknowledged more widely within the European policy discourse.

The importance of 'places and spaces' in youth work contexts is also widely acknowledged, for example that 'young people can find a space to express themselves' (EC, 2014: 35). The $2^{\text {nd }}$ Declaration on Youth Work emphasises the importance of: 'creating autonomous spaces for youth work practice' (European Youth Work Convention, 2015: 5) and the Council of Europe Recommendation recognises that these spaces should be fun (CofE, 2017:4). The 
participative nature of youth work spaces is also emphasised where: 'young people are all viewed as being equal in the decision-making process... to give young people complete ownership of the service (EC, 2014: 18).

Within the area of 'relating to others' there are some significant contrasts. The references within European policy discourse to friendship and wider notions of sociability are somewhat limited. There are examples, such as: 'Youth work offers relationships and space to young people ... [to] spend their spare time there, have fun and enjoy life, meet friends and get to know new friends. (EC, 2015: 76). But these are however rare, friendship and sociability are not as central in European policy as they are to young people's experiences of youth work in this study. This point will be returned to later.

European policy discourse comprehensively acknowledges 'learning' within youth work. The 'Recommendation on Youth Work' (CoE, 2017) has eight separate references to learning, including life-long, peer, non-formal and informal learning. Youth work is specifically contrasted with formal learning by: 'offering developmental spaces [outside of schools]' (EC, 2015: 15). There is a widespread focus on skills acquisition (EC, 2016). A distinction is made between practical or tangible skills and 'soft skills' (EC, 2015: 19; 2014: 26), 'life skills' (CoE, 2018b: 3) or social skills (EC, 2014: 67) and it is the 'soft skills' which are given a greater prominence. These range from developing 'problem-solving and communication skills' (EC, 2014: 63) to 'teamwork, adaptability and flexibility ... and intercultural skills' (EC, 2014: 40) as well as leadership, intercultural competences, project management, and critical thinking (CoE, 2018b: 6). There is also an emphasis on the 'skills [needed] to contribute to prosperous, democratic and cohesive societies' (EC, 2018b: 1). Skill development is set in the context of 'employability and entrepreneurial skills' (EC, 2018b: 7). 'Young people gain skills which help them to gain jobs' (EC, 2014: 109) or lead them to further education or training.

The importance of activities is also highlighted within European policy. For example, volunteering is one of the eight fields of action ( $\mathrm{CoE}, 2010)$ and youth work is expected to provide a variety of volunteering opportunities for young people. The diversity of activities is also recognised where: 'Youth work is a 'keyword' for all kinds of activities with, for and by young people' (CoE, 2018a). However, there is a limited focus on young people's experiences and experiential learning per se, this highlights a problem which will be returned to later. 
'Social inclusion' is prominent in European youth work policy. It is one of the eight EU 'fields of action' (CoE, 2010) and is identified in the 'Recommendation for Youth Work', which advocates '[s]trengthening the active citizenship, participation and social inclusion of all young people, especially those who are at risk and marginalised' (CoE, 2017). Many of the exemplars of youth work $(\mathrm{EC}, 2014)$ communicate how youth work promotes young people's social inclusion, from re-engaging young people with formal education in Spain to increasing the prominence of young people's decision making in public spheres in France.

The development of young people's autonomy is central to European youth work policy where youth work is described as 'youth centric' (CoE, 2018a), and as enabling young people to set their own direction both within projects and within their own lives. For example, acknowledging a strong rights-based approach, which:

...should support young people in realising their full potential as autonomous members of society, enabling them to develop life plans and exercise their democratic citizenship.

(CofE, 2017)

\section{Resulting problems for European youth work policy}

\section{The importance of friendship}

As alluded to above there is a disparity between the emphasis on friendship and sociability in the stories from young people - where friendship, relating to others and sharing a social life are clearly of great importance to young people within the youth work context - and its relative absence in European youth work policy.

Where it is alluded to it tends to be premised on the notion that friendship is important for extraneous reasons - for example, that young people will publicise youth projects to their friends 'through word of mouth' (EC, 2014: 121), or where 'friends' are linked to increasing participation, i.e. that 'young people's participation also depends on whether their friends participate' (EC, 2014: 26). Friendship in policy terms is often framed as a means to an end something that is important in order for youth work to be successful and achieve its policy priorities - whereas young people see it as an end in itself. For young people, friends and friendship are at the very heart of youth work. 
According to young people's experiences of youth work in this study, friends, relationships, sociability and the emotional lives of young people are inherent in the success of youth work. This means that explicit policy goals of youth work (such as social inclusion and skills acquisition) must be explicitly premised on the ability of young people to make, foster and sustain friendships as well as wider relationships in youth work settings. The lack of acknowledgement of this important aspect of youth work is therefore a cause for concern. Friendship and sociability need to be built into youth work, rather than simply 'bolted on'. Youth work must be founded on an appreciation of peer networks (Davies, 2005, 2015). The pivotal role that youth workers play as facilitators and mediators in allowing young people to create new bonds and meet new people is foundational in many of youth work's successes, and these need to be recognised.

Friendship is increasingly being acknowledged as a complex, multi-layered phenomenon with innumerable personal and social benefits. These include the 'capacity to enhance one's well-being and to protect at-risk youth from problems within their families and the peer group' (Bukowski et al., 2009: 217). Graber et al. also point out that 'close friendships are an important potential protective mechanism' (2015: 338) for a wide range of young people. Furthermore, 'young people themselves often define the lack of friendships as the most important cause of social exclusion and marginalisation' (Korkiamäki, 2016: 35). Edmund (2014) is no doubt correct to conclude that friendships need to be given greater priority within a wide range of service sectors. This article argues that this is certainly the case for European youth work policy.

\section{The tension between the autonomy of young people and top-down policy priorities}

Clearly, significant developments have been made across many European institutions to articulate, promote and develop youth work. However, this research highlights a tension within these policy initiatives between the 'youth-centric' practices of youth work and topdown policy priorities. At the heart of this is what the 'EC White Paper on Youth' (EC, 2001) refers to as 'the complex question of young people's autonomy'. The CoE (2017) recommendation in many ways implicitly exemplifies this dual emphasis. First, it promotes youth work in its own right, placing young people's autonomy and self-direction centrally. For example, building on an explicit reference to the 'United Nations Convention of the Rights of the Child', the recommendation argues that youth work 'should support young people in realising their full potential as autonomous members of society, enabling them to 
develop life plans' (CoE, 2017). It also acknowledges 'the freedom and autonomy of youth organisations and other non-governmental organisations (NGOs) doing youth work'. Second, however, the recommendation continues to uphold the belief that youth work can and must play a vital role in the promotion of a broad range of wider policy goals. These include the development of:

- competences that facilitate life-long learning, active citizenship and labour market participation;

- various skills such as creativity, critical thinking, conflict management, digital and information literacy and leadership;

- intercultural understanding, social cohesion, civic participation.

(CoE, 2017).

Tensions in youth work are not exclusively centred on young people's autonomy however. A number of others are acknowledged in the 'Recommendation on Youth Work' where it calls for youth work to be both 'fun and serious, playful and planned. It should be characterised by accessibility, openness and flexibility and at the same time promote dialogue between young people and the rest of society' (ibid., authors' italics). Such tensions are not new to youth work and neither are they specific to European youth work policy formation, but they are nonetheless important to acknowledge and recognise. As Bessant points out:

Youth work in the field of human services entails a variety of different interests and practices; it's a highly contested field characterized by paradox and contradiction between 'control and cure' or 'regulation and emancipation'.

(Bessant, 2012: 57)

This tension between youth-centric practices and policy priorities is important, because not only can it not be neatly resolved, but it also represents a fundamental tension at the heart of youth work practice. As Williamson rightly points out: 'An unsupported autonomy can be as useless as unconditional surrender' (2016: 61). The tension needs to be explicitly acknowledged and kept 'open', as a creative dynamic between top-down expectations and young people's lived experiences - the needs, ideas, aspirations and voices of young people themselves - and their involvement in an unfolding youth work practice. Indeed, as Siurala et al. (2016: 183) suggest: 
It is important to recognise the tension. Looking at it as a dichotomy can be used as a conceptual framework which sensitises us to discern phenomena and processes which otherwise might stay hidden.

\section{The diversity of young people}

Such tensions are not of course confined to the relationship between youth work and the policy process. Numerous tensions result from the diversity of young people themselves. 'Young people are not a homogeneous group' (Novak, 1997: 13), they reflect the multiple social divisions within wider society. Youth work can successfully engage with such diversity and help promote both social and cultural capital (Coburn, 2011). Young people's experience of youth work in this study confirms this, for example many of the 151 Italian stories reflected an appreciation of diversity, leading to the final code of: 'relating to others and valuing diversity'. Young people acknowledged how the youth setting encouraged reflection on: 'their own diversity as well as other people's' and encouraged young people to recognise and value that: 'we are all different'.

To some extent, such diversity is acknowledged within European policy discourse (Prügl \& Thiel, 2009). However such divisions are crucial in understanding and responding effectively to young people's diverse experience, not least because it produces conflicting priorities and competing needs. This ranges from the differing needs of girls and young women resulting from inherent sexism (Batsleer, 2013), responding to the racism experienced by black and minority ethnic young people (Craig, 2018; Bowler \& Razak, 2019), the varied needs of disabled young people (Slater, 2015), and responding to the concerns of lesbian, gay and bisexual young people (LGBT) (Formby, 2017).

How young people's diverse experience is incorporated and responded to in open access youth work is complex, not least given the intersectionality - how categories of identity are interwoven - and identity is a complex mix resulting in numerous advantages and disadvantages (Carastathis, 2016). So for instance the experiences of young women will vary depending on their class and ethnicity (Williams, 2009) and youth workers must be aware of this intersectionality.

In responding to these complex issues of diversity in open access youth work, first and foremost prejudice, discrimination and resulting oppression must be openly discussed and appropriately challenged, if youth work is to be part of the solution and not part of the 
problem (Thomson, 2012). Youth workers must also be proactive and enable educative conversations with young people increasing awareness, understanding and the appreciation of diversity. Youth workers must be cognisant of the environment of the youth settings and spaces must also reflect diversity (Heathfield, 1988). However, in deciding how to best respond to issues of diversity the pros and cons of integrated versus separate provision must also be weighed up. Open youth work settings can provide the opportunity to resolve intergroup conflict (Watkins, 2007). But it may also be necessary to provide separate spaces for example in responding to the particular needs of Muslim young people (Roberts, 2006) or providing separate safe spaces for LGBT young people (Formby, 2017). The kinds of experience created in youth spaces is also different - there are clear differences between a support group and one which promotes youth activism (Devlin, 2015). Considerations of these 'differing experiences' alludes to a further problem.

\section{Experiential learning}

As we saw earlier, European youth work policy embraces learning in a broad sense, however it has a limited acknowledgement of experiential learning. There are some exceptions to this. For example, the EC suggest: 'youth work should and must respond to the different needs, interests and experiences of young people' (EC, 2015: 76) and the $\mathrm{CoE}$ argue youth work creates: 'supportive and experiential learning environments for young people (CofE, 2020c). Nevertheless, even in these limited instances young people's experiences are often linked to specific policy priorities such as gaining of intercultural understanding' (EC, 2018b: 3); through the popular European concept of 'mobility'. This is described as providing: 'opportunities for young people to experience exchanges, cooperation and civic action in a European context first-hand' (EC, 2018b: 5).

Its emphasis on skills acquisition, and activities, often in the context of employability, also mitigates against the embracing of young people's experience as the locus of learning. One of the problems is learning in European youth work policy is broadly defined and is often conflated with life-long, peer, non-formal as opposed to informal learning (CoE, 2017). All these types of learning are very different, particularly the difference between non-formal and informal learning. The former whilst geared to identified needs outside of formal educational settings, it also has a clear pre-set agenda (invariably established by the educator), has a clear structure, focus and objectives (Smith, 2001). On the contrary the starting point of informal 
learning is the experience of the young people, it is person centred and responds to their context (Davies, 2015; Ord, 2016).

The question for youth work is posed by Taylor (2017):

A black, working-class heterosexual young woman does not experience the world in quite the same way as a white middle-class lesbian Christian young woman. Their personal and social development is intimately related to their biographies, to their circumstances, which both differ and are similar. How is this to be taken into account?

Only experiential learning can appropriately respond to this question which the diversity of young people's lives asks of youth work practice. Experiential learning follows Dewey $(1916,1938$; Ord, 2012) and experience is at the heart of the educational process, learning is lived experience, or as Jeffs and Smith put it: 'Learning in life as it is lived' (2005: 4). For Dewey learning does not result from discreet or separate activities or the provision of 'experiences', it is not the acquisition of a set of new skills but learning is transformational, it is our experience of the world which is changed, what is educated, as argued by (Dewey, 1916: 59):

The concept of education is a constant reorganising or reconstructing of experience... the direct transformation of the quality of experience... We thus reach a technical definition of education: It is that reconstruction or reorganisation of experience which adds to the meaning of experience and which increases ability to direct the course of subsequent experience.

As one of the final codes from the Estonian youth work stories confirms young people acknowledge that youth work: 'broadens the spectrum of experiences' and European youth work policy needs to recognise more explicitly the centrality of both young people's experience and the role of experiential learning in youth work.

\section{Conclusion}

It is reassuring that the experiences of the 844 young people who provided stories of the positive impact of youth work broadly cohere with the European youth work policy goals. However, this study also reveals that the enactment of these policy goals is not entirely unproblematic: Firstly, there is insufficient acknowledgement of friendship and the emotional 
life of young people in the framing of youth work in European policy discourse. Secondly there are tensions both between the top-down policy priorities and the youth-centric principles of youth work, as well as within the tensions generated by the diversity of young people. Finally, it is only with an explicit commitment to experiential learning that youth work can embrace the lived experiences of young people as the locus for learning.

'This research was supported with a €306,000 grant from Erasmus + Key Action 2, in the field of 'Strategic Partnerships for Youth', under Grant number: 2015-3-UK01-KA205-022861.

The Scottish element of the project was funded by the Scottish Youth Work Research Steering Group.

ii The term 'field' is an official term for a policy priority area within European policy.

iii Worked out on the basis that '[a]t least $28 \%$ of total Erasmus+ budget [is designated] for KA2 ... [as a whole, and of which] at least $10 \%$ [is allocated] for the Youth field' (Deloitte, 2014, p. 25).

iv For further information on the methodology see Davies (1996); Davies \& Dart (2005); Zandee \& Cooperrider (2008); and Cooper (2018).

$\checkmark$ The Scottish element was a separate sister project but followed the same format of data collection and analysis - the data was analysed entirely separately without any prior knowledge of the other five.

vi Whilst the impact of youth work may well vary depending on the ages of the young people, it is beyond the scope of this particular study to disaggregate and analyse the data by age. This would, however, make an interesting follow-up study.

vii 3 youth work organisations were recruited in both England and Scotland making 6 from the UK in total, however these remained 2 distinct data sets and were collected and analysed separately. Estonia collected data from 3 regions so collected data from more than 3 youth centres.

viii MJC is an abbreviation for 'Maison des Jeunes et de la Culture' - a youth club in France. 


\section{References}

Ambresin, A-E.; Bennett, K.; Patton, G.C.; Sanci, L.A. and Sawyer, S.M (2013) Assessment of Youth-Friendly Health Care: A Systematic Review of Indicators Drawn From Young People's Perspectives, Journal of Adolescent Health 52 (2013) 670-681

Batsleer, J. (2013) Youthworking with Girls and Women in Community Settings. A Feminist Perspective. London Ashgate Arena

Bessant, J. (2012), 'Youth work and the education of professional practitioners in Australia', in Fusco, D. (ed.) Advancing Youth work: Current trends, critical questions, New York: Routledge, 52-68.

Bohn, I. (2008), The Socio-Economic Scope of Youth Work in Europe, Frankfurt/Main:.ISS (Institut für Sozialarbeit und Sozialpädagogik).

Bukowski, W. M., Motzoi, C., \& Meyer, F. (2009), 'Friendship as process, function, and outcome' in K. H. Rubin, W. M. Bukowski, \& B. Laursen (eds.), Social, emotional, and personality development in context. Handbook of Peer Interactions, Relationships, and Groups, New York and London: Guilford Press, 217-231.

Bowler, R. and Razak, A. (2019) Continuities and Change: Some reflections on 21 years of antiracist youth work. In youth and policy, https://www.youthandpolicy.org/articles/continuities-and-change-some-reflectionson-21-years-of-anti-racist-youth-work/ [accessed 09.06.20]

Carastathis, A (2016) Intersectionality: Origins, Contestations Horizons, Lincoln Nebraska: UNP

Coburn, A. (2011) Building social and cultural capital through learning about equality in youth work in Journal of Youth Studies, 14, 4, 475-491

Commission of the European Communities (1990), 'Proposal for a Council Decision adopting an action programme to promote youth exchanges and mobility in the Community — the 'Youth for Europe' programme', COM(90) 470 final, Official Journal of the European Communities (OJ) C 308, 6.

Commission of the European Communities (1993a), 'Priority actions in the youth field, Activity report 1992', COM(93) 521 final, Brussels.

Commission of the European Communities (1993b), Proposal for a European Parliament and Council Decision adopting the 'Youth for Europe III' programme: designed to promote the development of exchanges among young people and of youth activities in the Community "Youth for Europe" programme. COM(93) 523 final, Brussels.

Commission of the European Communities (2009) 'EU Strategy for Youth - Investing and Empowering',http://cdn02.abakushost.com/agenzijazghazagh/downloads/investing_e mpowering_en.pdf [accessed 15.04.2019]. 
Cooper, S. (2018), Participatory Evaluation in Youth and Community Work: Theory and Practice, Oxon: Routledge.

Craig, C (2018) (ed) Community Organising Against Racism: 'Race, Ethnicity and Community Development, Bristol: Policy Press

Council of Europe (1995), 'All Different - All Equal', https://www.europewatchdog.info/en/instruments/campaigns/all_different_all_equal/ [accessed 15.04.2019].

Council of Europe (2010), 'Resolution of the Council and of the Representatives of the Governments of the Member States, meeting within the Council, on youth work', 2010/C 327/1, http://eur-lex.europa.eu/legalcontent/EN/TXT/PDF/?uri=OJ:C:2010:327:FULL\&from=EN [accessed 17.02.2020].

Council of Europe (2017), 'Recommendation on Youth

Work',https://search.coe.int/cm/pages/result_details.aspx?objectid=0900001680717e7 $\underline{8}$ [accessed 15.04.2019].

Council of Europe (2018a), 'Youth Work Essentials', https://www.coe.int/en/web/youthportfolio/youth-work-essentials [accessed 23.04.2018].

Council of Europe (2018b), 'Engaging, Connecting and Empowering young people: a new EU youth strategy': https://eur-lex.europa.eu/legalcontent/EN/TXT/PDF/?uri=OJ:C:2018:456:FULL\&from=EN [accessed 17.02.2020].

Council of Europe (2020,a) Mission and Mandate of European Youth Centres, https://www.coe.int/en/web/youth/mission-andmandate\#: :text=Brief\%20history,of\%20Central\%20and\%20Eastern\%20Europe [accessed 04.06.2020]

Council of Europe (2020,b) Ministerial Conferences https://www.coe.int/en/web/youth/ministerialconferences\#: :text=The\%20first $\% 20$ European $\% 20$ Conference $\% 20$ of,of\%20this $\% 20$ year\%20in\%20Europe. [accessed 04.06.2020]

Council of Europe (2020c) Resolution of the Council and of the Representatives of the Governments of the Member States meeting within the Council on the Framework for establishing a European Youth Work Agenda (2020/C 415/01) https://eurlex.europa.eu/legal-content/EN/TXT/?uri=CELEX\%3A42020Y1201\%2801\%29

Davies, B. (2005), 'Youth Work: A Manifesto for Our Times', Youth \& Policy, 88, 5-27.

Davies, B. (2015), 'Youth Work: A Manifesto For Our Times - Revisited', Youth \& Policy $114,96-117$. 
Davies, R. (1996), 'An evolutionary approach to facilitating organisational learning: An experiment by the Christian Commission for Development in Bangladesh.' in D. Mosse, J. Farrington and A. Rew (eds), in Development as Process: Concepts and Methods for Working with Complexity. London: Routledge, 68-83.

Davies, R. and Dart, J. (2005), The 'most significant change' (MSC) technique, A guide to its use, https://www.mande.co.uk/wp-content/uploads/2005/MSCGuide.pdf [accessed 12.02.2020].

Davis, W.M. Shoveller, J.A Oliffe, J.L. and Gilbert, M (2012) Young people's perspectives on the use of reverse discourse in web-based sexual health, Culture, Health and Sexuality, 14 (9/10) 1065-1079

Deloitte (2014). A quick guide to EU Funding. Retrieved from https://www2.deloitte.com/content/dam/Deloitte/cy/Documents/finance/CY_Finance_EU Funding2014-2020Guide_Noexp.pdf

Denney, R. Meaney, S. Cronin, M. Arensman, E. (2020) The psychosocial impacts of cybervictimisation and barriers to seeking social support: Young people's perspectives, Children and Youth Services Review 111, 104872

Devlin, C. (2015) (Ed.), Prejudice and pride: LGBT activist stories from Manchester and beyond. Manchester: Hammer on Press.

Dewey, J. (1916) Democracy and Education. An introduction to the philosophy of education (1966 edn.), New York: Free Press.

Dewey, J. (1938) Experience and Education, (1997 edn.) New York: Macmillan.

Edmund, R. (2014), 'Longing to belong: children in residential care and their experiences of peer relationships at school and in the children's home' Child and Family Social Work 2014, 19, 194-202.

Estonia (2018), 'Youth Work

Act',https://www.riigiteataja.ee/en/eli/ee/520122013004/consolide/current [accessed 2.03.2018].

European Commission (2001), 'European White paper on Youth - A new impetus for European youth' [COM(2001) 681 final, https://eur-lex.europa.eu/legalcontent/EN/TXT/?uri=LEGISSUM:c11055 [accessed 02.01.2020].

European Commission (2014), 'Working with Young people: The Value of Youth Work in the European Union', http://ec.europa.eu/assets/eac/youth/library/study/youth-workreport_en.pdf [accessed 21.04.2019].

European Commission (2015), 'Quality youth work: A common framework for the further development of youth work, report from the expert group on youth work quality systems in the EU member states', 
http://ec.europa.eu/assets/eac/youth/library/reports/quality-youth-work_en.pdf [accessed 19.04.2019].

European Commission (2016) 'A New Skills agenda for Europe'

https://ec.europa.eu/transparency/regdoc/rep/1/2016/EN/1-2016-381-EN-F1-1.PDF [accessed 24.04.2019].

European Commission (2017), 'The Contribution of Youth Work to Preventing Marginalisation and Violent Radicalisation: A practical toolbox for youth workers \& recommendations for policy makers', http://www.injuve.es/sites/default/files/informe_coe.pdf, [accessed 15.04.2019].

European Commission (2018), 'EU Youth Strategy 2019-2027', available at: https://ec.europa.eu/youth/policy/youth-strategy_en [accessed 17.02.20]

European Commission (2018b), 'Engaging, Connecting and Empowering young people: a new EU youth strategy':

https://ec.europa.eu/youth/sites/youth/files/youth_com_269_1_en_act_part1_v9.pdf [accessed 16.04.2019].

European Commission (2018c). 2019 Annual work programme for the implementation of

"Erasmus +": The union programme for education, training, youth and sport $\mathrm{C}(2018)$

6572 of 11 October 2018. Retrieved from https://ec.europa.eu/programmes/erasmusplus/resources/documents/annual-work-programmes_en file:///C:/Users/Jon Ord/Downloads/Erasmus+ Work Programme 2019.pdf

European Commission (2020) The Reinforced Youth Guarantee. Retrieved from https://ec.europa.eu/social/main.jsp?catId=1079\&langId=en

European Parliament (1981), 'Resolution on Youth Activities'. Official Journal of the European Communities, (OJ) C 77, 1981, 58.

European Parliament (1983), 'Resolution on a European Community Programme to promote Youth Exchange (European Youth Exchange Programme)', OJ C 184, 1983, 22. Brussels.

European Youth Work Convention (2015) https://pjpeu.coe.int/documents/1017981/8529155/The+2nd+European+Youth+Work+Declarati on_FINAL.pdf/cc602b1d-6efc-46d9-80ec-5ca57c35eb85 [accessed 22.04.2019].

Fitzsimons, A. Hope, M. Cooper, C. \& Russell, K. (2011) Empowerment and Participation in Youth Work, Exeter: Learning Matters

Formby, E. (2017) Exploring LGBT spaces and communities London: Routledge

Gavrielides T. (2017) European Democracy in crisis: Building a bridge between crosssectoral and youth-led policy in Magda, N. Marti, T. (Editors-in-chief ) and Dunja Potočnik, Andrei Salikau (Editors) Needles in Haystacks, Finding a way forward for 
cross-sectoral youth policy, Council of Europe and European Commission, Strasbourg

Graber, R., Turner, R. and Madill, A. (2016), 'Best friends and better coping: Facilitating psychological resilience through boys' and girls' closest friendships', British Journal of Psychology 107, 338-358.

Heathfield, M. (1988) The Youth Work Response to Lesbian and Gay Youth, Youth \& Policy, 23, 19-22

Jeffs, T. and Smith, M.K. (2005) Informal Education, Conversation, Democracy and Learning, ( $3^{\text {rd }}$ Edn.) Derby: Education Now.

Korkiamäki R. (2016), 'Friendship as Potential? The Recognition of Teenagers' Peer Relationships at School' 'Open Journal of Social Sciences', 2016, 4, 34-4.

Lahusan, C. Schultz, N. and Graziano P. R. (2013), Promoting social Europe? The development of European youth unemployment policies, International Journal of Social Welfare, 22, 3, 300-309.

Larkins, C. and Wainwright, J. (2020) 'If rich people gave money to poor people': Young people's perspectives on reducing offending and implications for social citizenship, Children and Youth Services Review 110,104702

NYA (2018) Hear by Right: Developing best practice in young people's participation, https://nya.org.uk/wp-content/uploads/2018/06/Hear-by-Right-.pdf [accessed 02.06.20]

Novak, T. (1997) Young People Class and Poverty in Jones, H. (ed) A Classless Society? London, Routledge

Ord, J. (2012), 'John Dewey \& Experiential Learning: Developing the theory of youth work' Youth \& Policy, 108, $55-72$.

Ord, J. (2016), Youth Work Process Product and Practice: Creating an authentic curriculum in work with young people, London: Routledge.

Prügl, E. \& Thiel, M. (2009) Diversity in Europe, London: Palgrave Macmillan.

Roberts, J., 2006. Making a Place for Muslim Youth Work in British Youth Work, Youth \& Policy, 92, pp.19-31.

Saldana, J. (2016) The Coding Manual for Qualitative Researchers, 3rd Edition, London: Sage.

Siurala, L., Coussée, F., Suurpää, L. and Williamson, H (2016), 'Bridging youth work, but on whose terms?' in Siurala, L., Coussée, F., Suurpää, L. and Williamson, H. (eds) The History of Youth Work in Europe: Autonomy through dependency - Histories of co- 
operation, conflict and innovation in youth work Volume 5, Strasborg: Council of Europe Publishing.

Slater, J. (2015) Youth and disability: a challenge to Mr Reasonable, Farnham: Ashgate press

Smith, M. K. (2001). 'What is non-formal education?', The encyclopedia of pedagogy and informal education. [https://infed.org/mobi/what-is-non-formal-education/, [06.06.2020].

Taylor, T. (2017) Treasuring, but not measuring: Personal and social development, Youth \& Policy, https://www.youthandpolicy.org/articles/treasuring-not-measuring/ [accessed [05.06.2020]

Thomson, N. (2012) Anti Discriminatory Practice, 5th edn, Basingstoke: Palgrave

UNAIDS (2020) Nothing for us, without us

https://www.unaids.org/en/resources/presscentre/featurestories/2018/july/nothing-forus-without-us [accessed 24.10.2020]

Unwin, J. and Wellington, J. (2001) Young people's Perspectives on Education, Training and Employment: realising their potential, London: Kogan Paul

Visser, K. (2020) 'I really wanted to stay in the same neighbourhood...' neighbourhood choice and satisfaction in the context of forced relocation - young people's perspectives, Journal of Housing and the Built Environment 35, (2)1, 443-460

Watkins, N.D., Larson, R.W. and Sullivan, P.J. (2007) 'Bridging intergroup difference in a community youth program', American Behavioral Scientist, Vol. 51, No. 3, pp. 380402.

Williamson, H. (2016) 'Introduction to The "magic triangle": balancing autonomy and dependency in the interests of youth work' in Siurala, L., Coussée, F., Suurpää, L. and Williamson, H. (eds) The History of Youth Work in Europe: Autonomy through dependency - Histories of co-operation, conflict and innovation in youth work Volume 5: Strasborg: Council of Europe Publishing.

Williamson, H. and Coussée, F. (2019), 'Reflective Trialogue: Conclusions from the History Project - Twelve trilemmas for youth work', in H. Williamson and T. Basarab (eds), The history of youth work in Europe Volume VII: Pan-European and Transnational youth organisations \& The overall lessons learned from the history project, Strasbourg: Council of Europe

Williams, R.L. (2009) 'Developmental issues as a component of intersectionality: Defining the Smart-Girl Program', Race, Gender \& Class, Vol. 16, No. 1-2, pp. 82-101.

Zandee, D. and Cooperrider, D. (2008) 'Appreciable worlds, inspired inquiry.' in P. Reason and H. Bradbury (eds.) Handbook of Action Research ( $2^{\text {nd }}$ Ed.), London: Sage Publications, 190-198. 